\title{
FOR YOUR BOOKSHELVES ...
}

All figures given in dollars are in U.S. funds. Symbols listed are as follows: $C=$ Cloth, $P=P$ aper, $F=F l e x i c o v e r, H=H a r d c o v e r$.

NEW BOOKS

Amstutz, G.C. et al. (eds.) ORE GENESIS, THE STATE OF THE ART. Society for Geology Applied to Mineral Deposits, Special Publication No. 2. Springer-Verlag, 1982, 780p., \$65.00. Available from Springer-Verlag, New York, Inc., 175 Fifth Avenue, New York, NY 10010 , U.S.A.; or SpringerVerlag, Heidelberger Platz 3, D-1000 Berlin 33, F.R.G.

Anderson, J.G.C. and Owen, T.R. FIELD GEOLOGY IN THE BRITISH ISLES. Pergamon Press, 1982. 300p., \$46.00 (H); \$22.10 (F). Available from Pergamon Press Ltd., Headington Hill Hall, Oxford OX3 OBW, U.K.; or Pergamon Press Inc., Maxwell House, Fairview Park, Elmsford, New York 10523, U.S.A.; or Pergamon Press (Aust.) Pty. Ltd., P.O. Box 544, Potts Point, NSW 2011, Australia; or other Pergamon Press offices.

ATLAS DE PHOTO-INTERPRETATION, Méthode d'ćtude et de recherches de l'eau souterraine des rockes cristallines de l'Afrique de l'ouest, vol, 3. Géohydraulique, 1981, 39p. plus 50 examples, price not listed. Available from Géohydrauliques, 10 rue Eugéne Renault, 94700 Maisons - Alfort, France.

Augustithis, S.S. ATLAS OF THE SPHAEROIDAL TEXTURES AND STRUCTURES AND THEIR GENETIC SIGNIFICANCE. Theophrastus Publications S.A., 1982, 329p., $\$ 50.00$ (C). Postfree. Available from Theophrastus Publications S.A., 33 J. Theologou Str., Zographou, Athens, Greece.

Axelrod, Daniel I, ROLE OF VOLCANISM IN CLIMATE AND EVOLUTION. Geological Society of America Special Paper 185, 1981, 59p., \$7.00. Available from Geological Society of America, P.O. Box 9140, Boulder, Colorado 80301, U.S.A.

Baker, V.R. THE CHANNELS OF MARS. University of Texas Press, 1982, 198p., \$39.95. Available from the University of Texas Press, P.O. Box 7819 , University Station, Austin, Texas 78712 , U.S.A.

Barnes, J.W. BASIC GEOLOGICAL MAPPING (Geological Society of London Handbook). John Wiley, $1981,128 \mathrm{p} . \$ 12.95(\mathrm{P})$. Available from John Wiley \& Sons, Inc., 605 - 3rd Avenue, New York, NY 10016, U.S.A.; or John Wiley \& Sons, Baffins Lane, Chichester, Sussex POI9 IUD, U.K.

Bates, C.C., Gaskell, T.F., and Rice, R.B. GEOPHYS ICS IN THE AFFAIRS OF MAN, A Personalized History of Exploration Geophysics and its Allied Sciences of Seismology and Oceanography. Pergamon Press, 1982, 500p., $\$ 69.00(\mathrm{H}) ; \$ 28.80$ (F). Available from Pergamon Press, for address see Anderson and Owen listing.

Bates, Robert L. and Jackson, Julia A. OUR MODERN STONE AGE. William Kaufmann, 1982, 136p., \$18.95. Available from Williarn Kaufmann, Inc., 95 First Street, Los Altos, California 94022, U.S.A.

Beck, A.E. PHYSICAL PRINCIPLES OF EXPLORA TION METHODS: AN INTRODUCTORY TEXT FOR GEOLOGY AND GEOPHYSICS STUDENTS. John Wiley, 1981, 256p., \$39.95 (C); \$18.95 (P). Available from John Wiley \& Sons, for address see Barnes listing.

Berckhemer, Hans and Hsü, Kenneth (eds.) ALPINE - MEDITERRANEAN GEODYNAMICS. American Geophysical Union, Geodynamics Series, Vol. 7, 1982, 216p., \$17.00. Available from AGU, 2000 Florida Avenue NW, Washington, DC 20009 , U.S.A.

Bridges, E.M. and Davidson, D.A. (eds.) PRINCIPLES AND APPLICATIONS OF SOIL GEOGRAPHY. Longman, 1982, 297p., \$13.95. Available from Longman Inc., is W 4 th Street, Suite 1012 . New York, NY 10036, U.S.A.

Biidel, J. CLIMATIC GEOMORPHOLOGY (English translation). Princeton University Press, 1982, 443 p., $\$ 50.00(\mathrm{H}) ; \$ 18.50(\mathrm{C})$. Available from Princeton University Press, 41 William Street, Princeton, New Jersey 08540, U.S.A.

Budyko, M.I. THE EARTH'S CLIMATE: PAST AND FUTURE, International Geophysics Series, Vol. 29. Academic Press, 1982, 307p., \$39.50. Available from Academic Press, Inc., 111 Fifth Avenue, New York, NY 10003, U.S.A.; or Academic Press, Inc. (London) Ltd., 24/28 Oval Road, London NW 1 7DX, U.K.

Chadwick, M.J. and Lindman, N. (eds.) ENVIRONMENTAL IMPLICATIONS OF EXPANDED COAL UTILIZATION. Pergamon Press, 1982, 304p., $\$ 55.00(\mathrm{H})$. Avalable from Pergamon Press, for address see Anderson and Owen listing.

Condie, K.C. PLATE TECTONICS AND CRUSTAL EVOLUTION, 2nd edition. Pergamon Press, 1982, 350p., $\$ 65.00(\mathrm{H}) ; \$ 29.50(\mathrm{~F})$. Available from Pergamon Press, for address see Anderson and Owen listing.

Cooley, M.E. and Turner, R.M. APPLICATION OF LANDSAT PRODUCTS IN RANGE- AND WATERMANAGEMENT PROBLEMS IN THE SAHELIAN ZONE OF MALI, UPPER VOLTA, AND NIGER. U.S. Geological Survey Professional Paper P1058, 1982, 52p., \$6.00. Available from Superintendent of Documents, Government Printing Office, Washington, DC 20402, U.S.A.

Cracknell, A.P. (ed.) REMOTE SENSING IN METEOROLOGY, OCEANOGRAPHY AND HYDROLOGY. John Wiley, 1981, 542p., \$104.95 (C). Available from John Wiley \& Sons, for address see Barnes listing.

Craig, James R, and Vaughan, David J. ORE MICROSCOPY AND ORE PETROGRAPHY. John Wiley, 1981, 406p., \$29.95. Available from John Wiley \& Sons, for address see Barnes listing.

Craig, R.G. and Labovitz, M.L. (eds.) FUTURE TRENDS IN GEOMATHEMATICS. Pion Ltd., $1982,318 \mathrm{p}$., \$28.00. Available from Methuen, Inc., 733 Third Avenue, New York, NY 10017, U.S.A.

Deer, W.A., Howie, Robert A., and Zussman, Jack. ROCK FORMING MINERALS, 2nd edition, Vol. 1A: ORTHOSILICATES. John Wiley, 1981, 900p. $\$ 165.00$ (C). Available from John Wiley \& Sons, for address see Barnes listing.

Dodd, R.J. and Stanton, R.J. PALEOECOLOGY, CONCEPTS AND APPLICATIONS. John Wiley, 1981, 559p., \$39.95 (C). Available from John Wiley \& Sons, for address see Barnes listing.

Drescher-Kaden, F.K. and Augustithis, S.S. (eds.) TRANSFORMISTS' PETROLOGY. Theophrastus Publications, 1982, 305p., $\$ 20.00$, postfree. Available from Theophrastus Publications S.A., for address see Augustithis listing.

Elf-Aquitaine. EXPLORATION FOR CARBONATE RESERVOIRS. Translated and updated by A. Reeckmann and G.M. Friedman. John Wiley, 1982, 213 p., $\$ 39.95$ (C). Available from John Wiley \& Sons, for address see Barnes listing.

Ernst, w. et al. (eds.) NATURAL RESOURCES AND DEVELOPMENT, Vol. I5. A biannual collection of recent German contributions concerning the exploration and exploitation of natural resources. Institute for Scientific Co-operation, 1982, $114 \mathrm{p}$., price not listed. Available from Institut für Wissenschaftliche Zusammenarbeit, Landhausstrasse 18, D-7400 Tübingen, F.R.G.; or Bundesanstalt für Geowissenschaften und Rohstoffe, Stilleweg 2, Hannover, F.R.G.

\section{Fergusson, J.E. INORGANIC CHEMISTRY AND}

THE EARTH, Chemical Resources, Their Extraction, Use \& Environmental Impact. Pergamon Press, 1982, 400p., $\$ 69.00(\mathrm{H}) ; \$ 34.50$ (F). Available from Pergamon Press, for address see Anderson and Owen listing.

Gillen, Con. METAMORPHIC GEOLOGY, An Introduction to Tectonic and Metamorphic Processes. George Allen \& Unwin, 1982,160p., 10 pounds
(H); 4.95 pounds (P). Available from George Allen \& Unwin, P.O. Box 18, Park lane, Hemel Hempstead, Herts. HP2 4 TE, U.K.

Govorukha, L.S. and Kruchinin, Yu. A. (eds.) PROBLEMS OF PHYSIOGRAPHIC ZONING OF POLAR LANDS. Amerind Publishing for the U.S. National Science Foundation, 1981, 242p., \$21.00. Available from National Technical Information Service, U.S. Department of Commerce, 5285 Port Royal Road, Springfield, Virginia 22161 , U.S.A.

Gray, John S. THE ECOLOGY OF MARINE SEDIMENTS. Cambridge University Press, 1981, 185 p., no price listed. Cambridge University Press, P.O. Box 110, Cambridge CB2 3RL, U.K.; or Cambridge University Press, 510 North Avenue, New Rochelle, NY 10801 , U.S.A.

Gregory, C.E. A CONCISE HISTORY OF MINING. Pergamon Pres5, 1981, 280p., \$30.00 (H). Available from Pergamon Press, for address see Anderson and Owen listing.

Gupta, H.K. and Delany, F.M. (eds.) ZAGROS HINDU KUSH - HIMALAYA: GEODYNAMIC EVOLUTION. American Geophysical Union Geodynamic Series, vol. 3, 1981, 323p., plus maps, $\$ 28.00$. Available from $A G U$, for address see Berckhemer and Hsü listing.

Gwalani, L.G. PETROLOGY OF DECCAN TRAPS AND BAGH BEDS OF DUGDHA-NASWADI GUJARAT. Somaiya Publications Pvt. Ltd., 1981, 107 p., 65 rupees. Available from Somaiya Publications Pvt. Ltd., 172 Mumbai Marathi Granthasangrahalaya Marg, Dadar, Bombay, India 400014.

Habashi, F. and Bassyouni, F.A. MINERAL RESOURCES OF THE ARAB COUNTRIES, 2nd edition. Chemecon Publishing Co., 1982, 60p. text, $34 \mathrm{p}$. maps, 50.00 pounds. Available from The British Sulphur Corp. Ltd., Parnell House, 25 Wilton Road, London SW IV INH, U.K.

Haimes, Yacov Y. (ed.) RISK/BENEFIT ANALYSIS IN WATER RESOURCES PLANNING AND MANAGEMENT. Plenum, 1981,304 p., $\$ 35.00 ; \$ 42.00$ (outside U.S.A. and Canada). Available from Plenum Publishing Corp., 233 Spring Street, New York, NY 10013 , U.S.A.; or Plenum Publishing Corp., 88/90 Middlesex Street, London E1 7E2, U.K.

Halbouty, Michel T. (ed.) ENERGY RESOURCES OF THE PACIFIC REGION. AAPG Studies in Geology No. 12, 1981, 578p., \$24.00 (AAPGSEPM members); $\$ 28.00$ (non-members). 51 of the 135 papers presented at the 1978 CircumPacific Energy and Mineral Resources Conference held in Honolulu, U.S.A. Available from A.A.P.G., Bookstore, P.O. Box 979, Tulsa, Oklahoma 74101, U.S.A.

Hamilton, A.C. ENVIRONMENTAL HISTORY OF EAST AFRICA: A STUDY OF THE QUATERNARY. Academic Press, 1982, 328p., \$49.50. Available from Academic Press, for address see Budyko listing.

Henley, S. NONPARAMETRIC GEOSTATISTICS. John Wiley, 1982, 139 p., \$24.95 (C). Available from John Wiley \& Sons, for address see Barnes listing.

Hill, M.N. THE SEA. Vol. I, PHYSICAL OCEANOGRAPHY, reprint 1982, 880p., \$55.00; Vol. 2, COMPOSITION OF SEA WATER, reprint 1982 , 570p., \$55.00. Available from Robert E. Krieger Publishing Co. Inc., P.O. Box 9542, Melbourne, Florida 32901 , U.S.A.

HYDROGEOLOGIC ATLAS OF THE PEOPLE'S RE PUBLIC OF CHINA (Written in Chinese and accompanied by an English legend.) Edited by The Institute of Hydrogeology and Engineering Geology, State Bureau of Geology, The People's Republic of China. Academic Press, 1982, 68 maps, 28p. English legend, \$150.00. Available from Academic Press, for address see Budyko listing. 
Ulubard EF et al MEASUREMENT OF TIME OF TRAVEL AND DISPERSION IN STREAMS BY DYE TRACING. U.S. Geological Survey Techniques of Water Resources Investigations TWI 03-A9. 1982, 44p., \$5.00. Available from Superintendent of Documents, Government Printing office, for address see Cooley and Turner listing.

Jenkins, D.G. and Murray, J.W. (eds.) STRATIGRAPHICAL ATLAS OF FOSSIL FORAMINIFERA. John Wiley, 1981, 2500.. \$79.95. Avallable from John Wiley \& Sons, for address see Barnes listing.

Jensen, M.L. and Bateman, A.M. ECONOMIC MINERAL DEPOSITS, revised 3rd edition. John Wiley, 1981, 593 p., \$26.95 (C). Available from John Wiley \& Sons, for address see Barnes listing.

Ladd, M.F.C. and Palmer, R.A. (eds.) THEORY AND PRACTICE OF DIRECT METHODS IN CRYSTALLOGRAPHY. Plenum, 1980, 436p. $\$ 35.00 ; \$ 42.00$ (outside U.S.A. and Canada). Avaitable from Plenum Publishing Corp., for address see Haimes listing.

La Verne et al. (eds.) NAZCA PLATE: CRUSTAL FORMATION AND ANDEAN CONVERGENCE. Geological Society of America Memoir 154. 1981, 824p., \$18.00. Available from GSA, for address see Axelrod listing.

Likens, Gene E. (ed.) SOME PERSPECTIVES OF THE MAJOR BIOGEOCHEMICAL CYCLES. SCOPE, ICSU, and John Wiley, 1981, 175p., 11 pounds. Available from John Wiley \& Sons, for address see Barnes listing.

Link, Peter K. BASIC PETROLEUM GEOLOGY. PennWell Books, 1982, 250p., \$40.00. Available from PennWell Books, P.O. Box 21288 , Tulsa Oklahoma. 74121 , U.S.A.

Little, Dennis L., Dils, Robert E., and Gray, John (eds.) RENEWABLE NATURAL RESOURCES: A MANAGEMENT HANDBOOK FOR THE 1980's. Westview Press, 1982, 316p., \$12.50. Available from Academic Book Center, Inc., Portland, Oregon 97213, U.S.A.

Loreau, Jean-Paul. SÉdIMENTS ARAGONITIQUES ET LEUR GENESE. Mémoires du Muséum Nationa d'Histoire Naturelle, Série C, Géologie, tome 47, 1982, 312p., 160FF. Available from Muséum National d'Histoire Naturelle, Service de Vente des Publications, 38 rue Geoffroy-Saint-Hilaire, 75005 Paris, France.

MacDonald, G.3. (ed.) THE LONG-TERM IMPACTS OF INCREASING ATMOSPHERIC CARBON DIOXIDE LEVELS. Ballinger, 1982, 252p., \$35.00. Available from Ballinger Publishing Co., 17 Dunster Street, Harvard Square, Cambridge, Massachusetts 02138 , U.S.A.

Mackenzie, Brian W. and Bilodeau. Michel L, ECONOMIC GUIDELINES FOR SMALL MINERAL DEPOSITS. Queen's University Centre for Resource Studies, Working Paper No. 25, 1982 , 66 p., $\$ 7.00$. Avalable from Centre for Resource Studies, Renouf Publishing Co. Ltd., 2182 St. Catherine Street West. Montreal, Quebec Canada H3M $1 \mathrm{M} 7$.

Makagon, Yuri F. HYDRATES OF NATURAL GAS Translated from Russian by W.J. Cieslewicz. PennWell Books, 1981, 176p., \$29.00. Available from PennWell Books, for address see Link listing.

Masters, P.M. and Flemming, N.C. (eds.) QUATERNARY COASTLINES AND MARINE ARCHAEOL OGY, Towards the Prehistory of Land Bridges and Continental Shelves. Academic Press, 1982, 540 p., no price listed. Available from Academic Press, for address see Budyko listing.

Mat thess, Georg. THE PROPERTIES OF GROUNDWATER. Translated by John C. Harvey. John Wiley, 1981, 432p., \$45.95 (C). Available from John Wiley \& Sons, for address see Barnes listing.

McKee, Edwin D. SEDIMENTARY STRUCTURES IN DUNES OF THE NAMIB DESERT, SOUTH WEST AFRICA. Geological Society of America Special Paper 188, 1982,64p., \$8.00. Avallable from Geological Society of America, for address see Axelrod listing.

Mestraud, J.-L. and Bessoles, B. GÉOLOGIE ET RESSOURCES MINÉRALES DE LA RÉPUBLIQUE CENTRAFRICAINE. ETAT DES CONNAISANCES Ă FIN 1963. Memoires du BRGM no. 60, 1982 , $185 \mathrm{p} ., 150 \mathrm{FF}$. Available from BRGM, Division Edition et vente, B.P. 6009,45060 Orleans Cedex, France.

EPISODES, Vol. 1982, No. 3.
THE MINERAL RESOURCES OF JAMAICA. GeOlog ical Survey Division Bulletin 8, 2nd edition, 1982, 104p., \$18.00. Available from Librarian, Geological Survey Division, P.O. Box 141, Kings ton 6, Jamaica.

Moseley. F. METHODS OF FIELD GEOLOGY. W.H. Freeman, 1981, 211 p., \$29.95(H); \$14.95(P). Available from W.H. Freeman and Co., 660 Market Street, San Francisco, California 94101, U.S.A.

Narashimhan, T.N. (ed.) RECENT TRENDS IN HY DROGEOLOGY, Geological Society of America Special Paper 189, 1982, 448p., \$32.00. Available from GSA, for address see Axelrod listing.

Neale, J.W. and Brasier, M.D. (eds.) MICROFOSSILS FROM RECENT SHELF SEAS (British Micropaleontological Society Series). John Wiley, 1981,355 p., $\$ 99.95$ (C). Available from John Wiley \& Sons, for address see Barnes listing.

OCEAN CRUSTAL DYNAMICS PROGRAM PLAN FOR THE 1980's. Joint Oceanographic Institutions Inc., 1982, 302p., no charge. Avallable from Joint Oceanographic Institutions Inc.. 2100 Pennsylvania Avenue NW, Washington, DC 20037. U.S.A.

Olson, Gerald W. SOILS AND THE ENVIRONMENT: A GUIDE TO SOIL SURVEYS AND THEIR APPLICATIONS. Chapman \& Hall, 1982, 178p. $\$ 29.50$ (H); \$16.95 (S). Available from Chapman \& Hall Ltd., 11 New Fetter Lane, London EC4P $4 \mathrm{EE}$, U.K.

Palmason. G. (ed.) CONTINENTAL AND OCEANIC RIFTS. A Study of the World Rift System. Amer can Geophysical Union, Geodynamics Series 8 , 1982, 320p., \$26.00 (30\% AGU member discount). Available from American Geophysical Union, for address see Berckhemer and Hsü.

Péwé, Troy L. (ed.) DESERT DUST: ORIGIN, CHARACTERISTICS, AND EFFECT ON MAN. Geological Society of America Special Paper 186, 1981 303 p., $\$ 30.00$. Available from Geological Society of America, for address see Axelrod listing.

Pickard, George L. and Emery, William J. DESCRIPTIVE PHYSICAL OCEANOGRAPHY. An Introduction, 4th enlarged edition. Pergamon Press, 1982,249 p. $\$ 11.95 / 5.95$ pounds (F); $\$ 35.00 / 17.50$ pounds $(\mathrm{H})$. Available from Pergamon Press, for address see Anderson and Owen listing.

Rachocki, A.H. ALLUVIAL FANS: AN ATTEMPT AT AN EMPIRICAL APPROACH. John Wiley, 1981, 161 p., \$35.00 (C). Available from John Wiley \& Sons, for address see Barnes listing.

von Rad, U., Hinz, K., Sarnthein, M., and Seibold, E. GEOLOGY OF THE NORTHWEST AFRICAN CONTINENTAL MARGIN. Springer-Verlag. 1982, 703p., \$49.00. Available from Springer Verlag, for address see Arnstutz et al. listing.

Rapp, R.H. THE EARTH'S GRAVITY FIELD TO DEGREE AND ORDER I8O USING SEASAT AL TIMETER DATA, TERRESTRIAL GRAVITY DATA, AND OTHER DATA, Rep. 322. The Ohio State University, 1981, 53p., no price listed. Available from Department of Geodetic Science and Surveying, The Ohio State University, Colum Dus, Ohio 43210 , U.S.A.

Rokityansky, I.l. GEOELECTROMAGNE TIC INVESTIGATION OF THE EARTH'S CRUST AND MANTLE. Translated from Russian by N.L. Chobotova et al. Springer-Verlag, 1981, 381 p., $\$ 70.50(\mathrm{C})$. Available from Springer-Verlag, for address see Amstutz et al. listing.

Rybach, L. and Muffler, L.J.P. GEOTHERMAL SYSTEMS: PRINCIPLES AND CASE HISTORIES. John Wiley, 1981, 359p., \$61.95 (C). Available from John $W$ iley \& Sons, for address see Barnes listing.

Saha, S.K. and Barrow, C.J. RIVER BASIN PLAN NING: THEORY AND PRACTICE. John Wiley, 1981,380 p. $\$ 45.50$ (C). Available from John Wiley \& Sons, for address see Barnes listing.

St-Julien, Pierre and Béland, Jacques (eds.) MAJOR STRUCTURAL ZONES AND FAULTS OF THE NORTHERN APPALACHIANS. Geological Association of Canada, Special Paper 24, 1982, 279p. $\$ 24.00$ (GAC members); $\$ 29.00$ (non-members). Available from GAC Publication Division, $\mathrm{c} / \mathrm{o}$ Business and Economic Service Ltd., 111 Peter
Street, Suite 509, Toronto, Ontario, Canada M5V $2 \mathrm{HI}$.

Saxov, Svend and Nieuwenhuis, 3.K. (eds.) MARINE SLIDES AND OTHER MASS MOVEMENTS. NATO Conference Series IV: Marine Sciences, Vol.

6. Plenum, 1982, 353p., \$32.50. Available from

Plenum Publishing Corp., for address see Haimes listing.

Schwab, F.L. (ed.) GEOSYNCLINES: CONCEPT AND PLACE WITHIN PLATE TECTONICS, Bench mark Papers in Geology, Vol. 64. Hutchinson Ross. 1982, $411 \mathrm{p} ., \$ 52.00$. Available from Academic Press, Inc., for address see Budyko listing.

Simpson, T.L. and Volcani, B.E. (eds.) SILICON AND SILICEOUS STRUCTURES IN BIOLOGICAL SYSTEMS. Springer-Verlag, 1981, 560p., \$98.90 (C). Available from Springer-Verlag, for address see Amstutz et al. listing.

Skinner, David R. INTRODUCTION TO PETROLEUM PRODUCTION OPERATIONS. Books to acquaint non-engineers with fundamentals of petroleum engineering. Vol. 1, RESER VOIR ENGINEERING, DRILLING, WELL COMPLETIONS, 1981, 200p., \$18.95; Vol. 2, FLUID FLOW, ARTIFICIAL LIFT, GATHERING SYSTEMS, AND PROCESSING 234 p., $\$ 24.95$ (C); Vol. 3, WELLSITE FACILITIES: WATER HANDLING, STORAGE, INSTRUMENTATION AND CONTROL SYSTEMS, $176 \mathrm{p} ., \$ 21.95$ (C). Available from Gulf Publishing Company Book Division, P.O. Box 2608, Dept. 16, Houston, Texas 77001 , U.S.A.

Sobolev, V.S., Lepezin, G.G., and Dobretsov, N.L. (ed5.) Translated by D.A. Brown. METAMORPHIC COMPLEXES OF ASIA. A companion work to and essentially a detalled explanation of "The Metamorphic Map of Asia," (Pergamon Press, 1979, 9 maps, \$15.00). Pergamon Press, 1982. 350p., $\$ 60.00(\mathrm{H})$. Available from Pergamon Press, for address see Anderson and Owen listing.

Sood, Mohan K. MODERN IGNEOUS PETROLOGY. John Wiley, 1981, 244p., \$27.50 (C). Available from John Wiley \& Sons, for address see Barnes listing.

Sposito, G. THE THERMODYNAMICS OF SOIL SOLUTIONS. Oxford University Press, 1981 , $223 p$., \$39.50. Available from Oxford University Press, Inc., 16-00 Pollitt Drive, Fair Lawn. New Jersey 07410 , U.S.A.

Stach, E. et al. STACH'S TEXTBOOK OF COAL PETROLOGY, 3rd edition. Translated by D.G Murchison, G.H. Taylor, and F. Zierke. Gebrüder Borntraeger, 1982, 535p., \$63.00. Available from Gebrüder Borntraeger, D-7000 Stuttgart 1, Johannestrasse 3A, F.R.G.

Tucker, M.E. THE FIELD DESCRIPTION OF SEDIMENTARY ROCKS (Geologica! Society of London Handbook). John Wiley, 1981, 128p., \$12.95 (P). Available from John Wiley \& Sons, for address see Barnes listing.

Tucker, M.E. SEDIMENTARY PETROLOGY: AN INTRODUCTION (Geoscience Text Series). John Wiley, 1981, 252p., $\$ 24.95(\mathrm{P})$. Available from John Wiley \& Sons, for address see Barnes listing.

Tucker, V.C.T. PALAEONTOLOGY: An Introduction. Pergamon Press, 1982, 220p., \$25(H); $\$ 12.50$ (F). Available from Pergamon Press, for address see Anderson and Owen listing.

Turcotte, Donald L. and Schubert, Gerald. GEODY NAMICS: APPLICATIONS OF CONTINUUM PHYSICS TO GEOLOGICAL PROBLEMS. John Wiley, 1982, 450p. \$31.04 (C). Available from John Wiley \& Sons, for address see Barnes listing.

Whiteman. Arthur. NIGERIA: ITS PETROLEUM GEOLOGY, RESOURCES AND POTENTIAL. Graham \& Trotman Ltd., 1982, Vol. 1, 176p.; Vol. 2, 238p.: both volumes $\$ 119.00 / 54.00$ pounds. Available from Graham \& Trotman Ltd., Sterling House, 66 Wilton Road, London SW IV IDE, U.K.

Wilson, Gilbert. INTRODUCTION TO SMALL-SCALE STRUCTURES. George Allen \& Unwin, 1982, $160 \mathrm{p} ., 10$ pounds $(\mathrm{H}) ; 4.95$ pounds $(\mathrm{P})$. Available from George Allen \& Unwin, for address see Gillen listing.

Zucher, Gordon L. and Hassan, E. El-Shall. A GUIDE TO MINERAL PROCESSING. (For owners and operators of small mines). Montana Bureau of Mines and Geology, 1982, 38p., $\$ 5.00$. Available Mines and Geology, $1982,38 \mathrm{p} ., \$ 5.00$. Available
from the Montana Bureau of Mines and Geology, Butte, Montana 59701 , U.S.A. 


\section{For Your Bookshelves}

PROCEEDINGS OF SYMPOSIA

COMPUTER APPLICATIONS IN GEOLOGY 1 \& 2. Proceedings of two meetings organized by the Geological Information Group and IAMG, London, 1979, 1980. Geological Society Miscellaneous Paper No. 14. May 1982, 284p., 6.75 pounds (GS Fellows); 12.75 pounds (Non-fellows). Available from the Geological Society of London, Burlington House, Piccadilly, London WIV oJl, U.K.

\section{DEVELOPMENT AND UTILIZATION OF MINERAL} RESOURCES IN AFRICA. Proceedings of the First Regional Conference, Addis Ababa, 198 !. UN Economic Commission for Africa, 1982. 307 p., 36.00 pounds. Avalable from the Inst $j-$ tution of Mining and Metallurgy, 44 Portland Place, London WIN 4BR, U.K.

THE EVOLUTION OF SEDIMENTARY BASINS Report of a Royal Society Discussion Meeting, June 1981. First published in Philosophical Transactions of the Royal Society, Series $A$, Vol. 305. The Royal Society, 1982, 338p., 41.50 pounds (U.K.); 43.65 pounds (overseas). Available from The Royal Society, 6 Carlton House Terrace, London SWIY SAG, U.K.

Freeland, Howard J., Farmer, David M. and Levings, Colin D. (eds.) FJORD OCEANOGRAPHY. NATO Conference Series IV, Marine Sciences Vol. 4. Proceedings of NATO Conference held in Victoria, British Columbia, Canada. Plenum, 1980,730 D. $\$ 69.50 ; \$ 83.40$ (outside U.S.A. and Canada). Available from Plenum Publishing Corp., for address see Haimes listing.

Glover, J.E. and Groves, D.I. (eds.) ARCHAEAN GEOLOGY. Proceedings of the 2nd International Archaean Symposium, Perth. Australia, 1980. Geological Society of Australia, Special Publication 7, 1981, 515p., \$27.50 Australian. Available from the Geological Society of Australia, 10 Martin Place, Sydney, N5W 2000, Australia.

Goodell, Philip C. and Waters, Aaron C. (eds.) URANIUM IN VOLCANIC AND VOLCANICLASTIC ROCKS. Proceedings of a symposium held with SW Section of AAPG, El Paso, Texas, U.S.A., 1980. American Association of Petroleum Geologists Studies in Geology No. 13, 1981, 331 p., $\$ 22.00$ (AAPG-SEPM members): $\$ 28.00$ (nonmembers). Available from AAPG, for address see Halbouty listing.

Gower, J.F.R. (ed.) OCEANOGRAPHY FROM SPACE. Proceedings of a COSPAR/SCOR/IUCRM Symposium held in Venice, Italy. Plenum, 1981, 998p., $\$ 95.00 ; \$ 114.00$ (outside U.S.A. and Canada). Available from Plenum Publishing Corp., for address see Haimes listing.

Lindblom, Ulf and Al-Hashimi, Wissam S. (eds.) UNDERGROUND STORAGE OF OIL AND GAS. Published papers of the First Arab Seminar held in Baghdad, October 1979, pages not listed, $\$ 80.00 / 1 . D .24$. Available from Arab Geologist Association, P.O. Box 1247, Central Post Office, Baghdad, Iraq.

Maurice, Y.T. (ed.) URANIUM IN GRANITES. Proceedings of Workshop held in Ottawa, 1980. Geological Survey of Canada Paper 81-23, 1982, 173 p., $\$ 12.00$ (Canada); $\$ 14.40$ (elsewhere). Available from Geological Survey of Canada, 601 Booth Street, Ottawa, Ontario, Canada KIA OE\&.

Middleditch, Brian S. (ed.) ENVIRONMENTAL EFFECTS OF OFFSHORE OIL PRODUCTION, The Buccaneer Gas and Oil Field Study. Proceedings of a Symposium held in Houston, Texas, U.S.A. Plenum, 1981, 464p., $\$ 49.50 ; \$ 59.40$ (outside U.S.A. and Canada). Available from Plenum Publishing Corp., for address see Haimes listing.

PETROLEUM AND THE MARINE ENVIRONMENT. Proceedings of the Petromar 180 Conference, Monaco. Graham and Trotman Ltd, 1981, 788p. $\$ 70.00$. Available from Crane, Russak \& Co., 3 East 44 th Street, New York, NY 10017, U.S.A.

RURAL WATER SUPPLY IN DEVELOPING COUNTRIES, Proceedings of a Workshop on training held in Zomba, Malawi, August 1980. International Development Research Centre (Canada), 1981. 144 p. U.S. orders available from Unipub, P.O. Box 433, Murray Hill Station, New York 10016 , U.S.A. (\$12.00); non U.S. orders available from Renouf, 61 Sparks Street, Ottawa, Ontario, Canada KIP 5 A5 $(\$ 9.00 \mathrm{cdn}$.).

EPISODES, Vol. 1982, No. 3.
Russ, John C. et al. (eds.) ADVANCES IN X-RAY ANALYSIS. Proceedings of 30th Annual Confer ence on Applications of X-Ray Analysis, Denver, U.S.A., 1981. Plenum, 1982, 398p., \$49.50. Available from Plenum Publishing Corp., for address see Haimes listing.

Schmidt, H. -L., Förstel, H., and Heinzinger, K. (eds.) STABLE ISOTOPES. Proceedings of the 4 th International Conference held in Julich. March 1981. Elsevier, 1982,758p., \$127.75/Dfl. 275.00. Available from Elsevier Scientific Publishing Co., P.O. Box 211, 1000 AE Amsterdam. The Netherlands; or Elsevier Scientific Publishing Co. Inc., 52 Vanderbilt Ave., New York, NY 10017 , U.S.A.; or D.A. Book Pty. Ltd., $1:-13$ Station Street, Mitcham, Victoria 3132, Australia.

SCIENTIFIC OCEAN DRILLING. Report of a Joint Oceanographic Institutions for Deep Earth Sampling Conference held at Austin, Texas, U.S.A., Nov. 1981. JOI, Inc., 110p., no charge. Available from JOI, Inc., 2100 Pennsylvania Avenue $\mathrm{NW}$

Washington, DC 20037, U.S.A

IUGS/AFFILIATES' PUBLICATIONS

Hawkes, H.E. (compiler) EXPLORATION GEOCHEMISTRY BIBLIOGRAPHY, to January 1981. Association of Exploration Geochemists, Special Vol. No. 11, 1982, 388p., \$7.50 (AEG members); $\$ 20.00$ (non-members). Available from AEG. P.O. Box 523, Rexdale, Ontario, Canada M9W 514.

Ramsbottom, W.H.C., Saunders, W.B., and Owens, B. BIOSTRATIGRAPHIC DATA FOR A MIDCARBONIFEROUS BOUNDARY. Subcommission on Carboniferous Stratigraphy, 1982, 156p., 5 pounds. Available from Subcommission on Carboniferous Stratigraphy Palaeontologica Department, Ring Road Halton, Leeds LS15 STQ, U.K.

Ross, Reuben J., Jr. et al. (eds.) THE ORDOVICIAN SYSTEM IN THE UNITED STATES. [UGS Publication No. 12, 1982, 73p., $\$ 10.00$. Available from UGS Secretariat, 77 rue Claude Bernard, 75005 Paris. France; or EPISODES office, Room 177 , 601 Booth Street, Ottawa, Ontario, Canada K1A OE8.

IUGS/AFFILIATES' NEWSLETTERS OR REPORTS

AFRICAN GEOSCIENCE. Newsletter No, 6, Aprit 1982, 5p.; No. 7, July 1982,6p. GSA and AGID. Departments of Physics and Geology, Ahmadu Bello University, P.O. Box 393, Zaria, Nigeria.

JURASSIC STRATIGRAPHY. Subcommision on Jurassic Stratigraphy, Newsletter No. 8, June 1982, 15p. Olaf Michelsen, Geological Survey of Denmark, Thoravej 31, DK-2400, Copenhagen NV, Denmark.

\section{IGCP PUBLICATIONS}

King, A.F. (compiler) THE CALEDONIDE OROGEN Guidebook for Avalon and Meguma Zones. IGCP Project 27, Report 9. NATO Advanced Study Institute, 1982, 308p., $\$ 20.00 \mathrm{Cdn}$, postage paid. Available from Department of Earth Sciences, Memorial University of Newfoundland, St. John's, Nfld, Canada A IB $3 \times 5$.

Merriam, D.F. (ed.) GEOLOGICAL CORRELATION No. 10, IGCP, 1982, 107p. IGCP Secretariat, Division of Earth Sciences, Unesco, Place de Fontenoy, 75700 Paris, France.

\section{IGCP NEWSLETTERS}

PROJECT 58: MID-CRETACEOUS EVENTS. NewS letter Vol. 9, No. 3, 1982, 4p. R. Reyment, Paleontologiska institutionen, Box 558, S-751 22 Uppsala, Sweden.

PROJECT 129: LATERITISA TION PROCESSES. Newsletter No. 4, June 1982, 48p. P.K. Banerji, Geological Survey of India, Orissa (N) Circle, 69 Kalpana Chawk, Bhubaneswar-751001, Orissa, India.

PROJECT 143: REMOTE SENSING AND MINERAL EXPLORATION. Newsletter No. 15, April 1982 , 17p. W.D. Carter, U.S. Geological Survey, 1925 Newton Square East, Reston, Virginia 22090 U.S.A.

PROJECT 148: QUANTITA TIVE STRATIGRAPHIC CORRELATION TECHNIQUES. Newsletter No. 6, Dec. 1981, 22p. F. Agterberg, Geolog ical Survey of Canada, 601 Booth Street, Ottawa, Ontario, Canada K1A OE 8.
PROJECT 156: PHOSPHORITES. Newsletter No. 11, July 1982, 45p. Arthur J.G. Notholt, Institute of Geological Sciences, Extibition Road, London SW7 2DE, U.K.

PROJECT 174: TERMINAL EOCENE EVENTS Newsletter No. 4, July 1982, I |p. C. Pomerol, Lab. de Géologie des Bassins Sédimentaires, 4 place Jussieu, 75230 Paris Cedex 05, France. NEW JOURNALS

CONTINENTAL SHELF RESEARCH. A companion journal to DEEP-SEA RESEARCH and PROGRESS IN OCEANOGRAPHY. This new quarterly journal first issue spring 1982, will publish papers on all aspects of research on the continental shelf. Editors: M. Collins, University College, Singleton Park, Swansea, SA2 8PP, U.K, and R.W. Sternberg. University of Washington. Seattle, Washington 98195, U.S.A. Annual subscription (1982) \$75.00; two year rate $(1982 / 83) \$ 142.50$; rate for individ-uals whose libraries subscribe $\$ 35.00$. For sub-scriptions and additional information write to Pergamon Press, for address see Anderson and Owen listing.

THE CRUST, Official newsletter of the Nigerian Mining and Geosciences Society. First issue December 1981. Distributed free of charge to all the society's members. Mr. C. Emuchay, Publicity Secretary, NMGS, Nigerian National Petroleum Corporation, P.M.B. 12650, Lagos, Nigeria.

INTERNATIONAL JOURNAL OF SOIL DYNAMICS AND EARTHQUAKE ENGINEERING. A new quarterly journal, first issue 1982. Subscriptions $\$ 12600$. Springer-Verlag New York Inc. Journal Fulfillment Services, Dept. J2560, P.O. Box 2485, Secaucus, New Jerscy 07094 , U.S.A.

MINAS A new journal, in Spanish, from Peru, 1981. For additional information write to Federico Ocampo Baldoceda, Director, Centro de Estudios e Investigacion Minera, de la Universidad Nacional de Tacna, Apartado Postal No. 117, Tacna, Peru, S.A.

\section{NEW MAPS}

PETROLEUM BASIN MAP OF THE UNITED STATES. Four color map. PennWell Books, 1982, 21 " $35 ", \$ 15.00$ (shipped in tube). Available from PennWell Books, for address see Link listing. MISCELLANEOUS

ASEQUA, Bulletin de Liaison, No. 62-63. Decembre 1981, 8sp. Salif DIOP, ASEQUA, Laboratoire de Géologie - Faculté des Sciences, Dakar Fann, Sénégal.

Brahic, A. (ed.) FORMATION OF PLANETARY SYSTEMS. Texts of all lectures presented at Centre National d'Etudes Spatiales 1980 Summer School, Grasse, France. CNES, 1982, 896p. 295FF. Available from Cepadues Editions, 11 rue Nicolas - Vauquelin. 31100 Toulouse, France. (Request English or French edition).

Bredehoef t, J.D. et al. STUDIES AND REPORTS N HYDROLOGY NO. 34 VO $:$ CONCEPTS, PROBLEMS, AND METHODS OF ANALYSIS WITH EXAMPLES OF THEIR APPLICATION. International Hydrological Programme, Working Group 8.1. Unesco. 1981, 235p., 70FF. Available from Unesco.

EARTHQUAKE DATA SERVICES AND PUBLICATIONS (INCLUDING TSUNAMI). National Oceanic and Atmospheric Administration, 1981, 14p., free. Available from the National Geophysical and Solar-Terrestrial Data Center, 325 Broadway, Boulder, Colorado 80303, U.S.A.

Hollander, Jack M. (ed.) ANNUAL REVIEW OF ENERGY Vol.6. Annual Reviews, 1981, 551 p.. $\$ 20.00$ (U.S. A.); $\$ 21.00$ (elsewhere). Postpaid. Avallable from Annual Reviews Inc., $4139 \mathrm{El}$ Camino Way, Palo Alto, California $94306-9981$, U.S.A.

Jackson, R.E. (ed.) STUDIES AND REPORTS IN HYDROLOGY No. 30, Project 8.3 of the International Hydrologica! Programme. Part I, 250 pages on theory, problems and solutions in contaminant hydrogeology. Part II, 20 case histories of aquifer contamination. Unesco, 1980, 440p., $125 \mathrm{FF}$. Available from Unesco.

REPORT OF THE DECADE: THE INTERNATIONAL DECADE OF OCEAN EXPLORATION. U.S. National Science Foundation, 1982,41 p., \$4.75. 